\title{
Identifikasi Faktor-Faktor yang Mempengaruhi Kemampuan Pemecahan Masalah Matematika
}

\author{
Ni Komang Vonie Dwianjani1'), I Made Candiasa²), Sariyasa ${ }^{3)}$
}

1,2),3) Universitas Pendidikan Ganesha Singaraja, Indonesia

Correspondence: $\mathbb{M}$ voniedwianjani@gmail.com

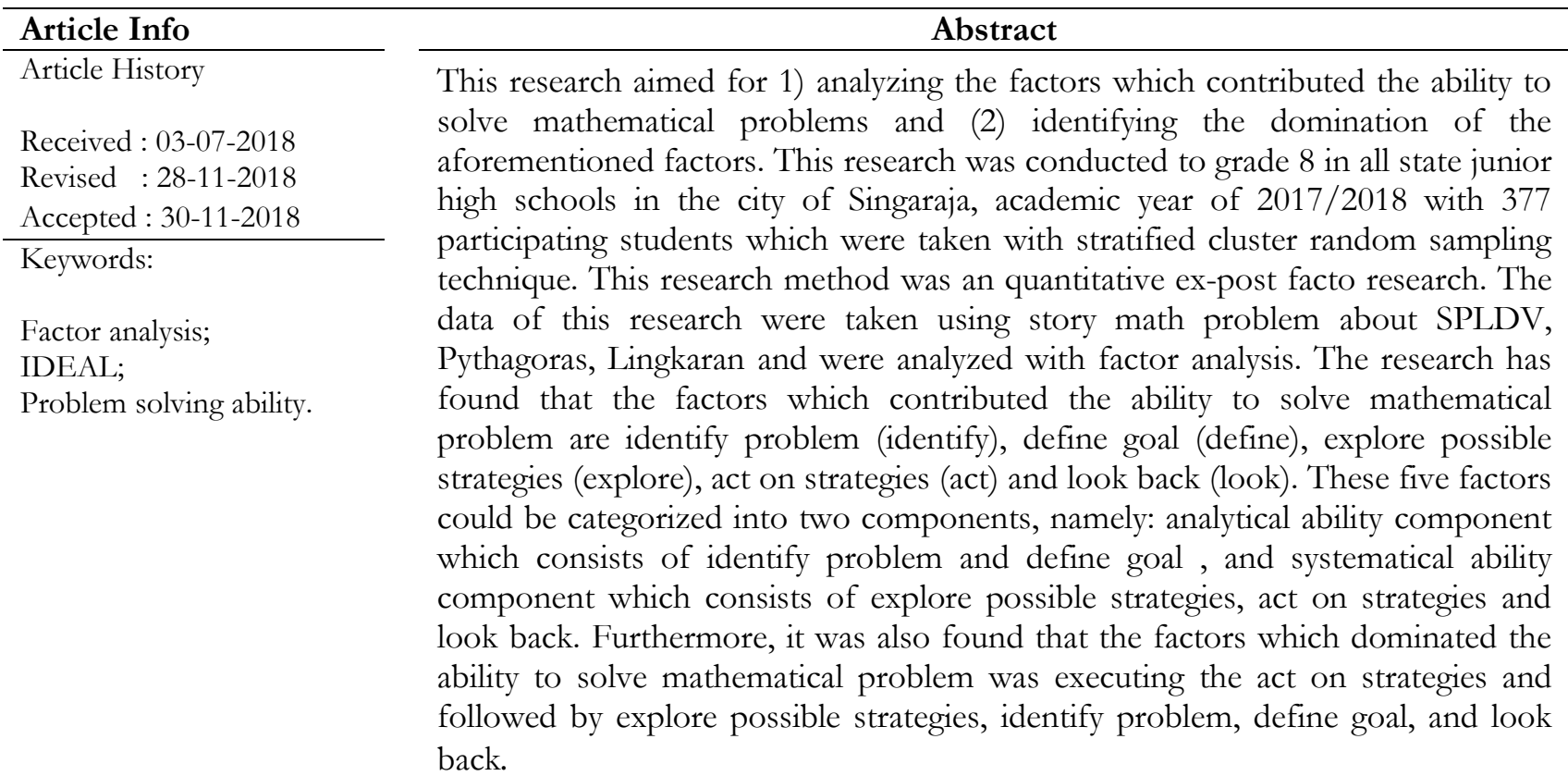

\section{PENDAHULUAN}

Pemecahan masalah merupakan salah satu tujuan utama mempelajari matematika, tujuan mata pelajaran matematika di sekolah untuk jenjang pendidikan dasar dan menengah adalah agar siswa mampu memecahkan masalah yang meliputi kemampuan memahami masalah, merancang model matematika, menyelesaikan model, dan menafsirkan solusi yang diperoleh [1].

Dari hasil dan evaluasi PISA 2015 kemampuan siswa di Indonesia masih tergolong rendah, salah satunya untuk bidang matematika berada di peringkat 69 dari 76 negara yang dievaluasi, hal ini menunjukan bahwa kemampuan pemecahan masalah matematika siswa di Indonesia masih tergolong rendah, sehingga dari hal tersebut sangat perlu dilakukannya identifikasi terhadap faktor-faktor yang mempengaruhi kemampuan pemecahan masalah matematika siswa di sekolah, dari sana nantinya akan bisa dirumuskan langkah-langkah untuk meningkatkan kemampuan pemecahan masalah matematika oleh guru di sekolah. Faktor penyebab dari rendahnya kemampuan siswa dalam memecahkan masalah PISA adalah siswa kurang terbiasa melakukan proses pemecahan masalah dengan benar [2].

Untuk mengetahui faktor-faktor yang mempengaruhi kemampuan pemecahan masalah siswa, salah satu caranya yaitu dengan mengidentifikasi indikator-indikator pemecahan masalah. Banyak strategi yang dapat mengukur hal tersebut, pemecahan masalah secara sederhana dari Gick (1986) yang terdiri dari tiga tahap yaitu mengkontruksi masalah (contruct problem representation), mencari penyelesaian (search for solution), dan menggunakan/mengimplementasikan (implement solution). Selanjutnya yang cukup popular salah satunya adalah Polya (1973) yang mengindikatorkan kemampuan pemecahan masalah 
siswa menjadi empat yakni memahami masalah (understand the problem), merencanakan pemecahan (devise a plan), menyelesaikan masalah (carry out the plan), dan memeriksa kembali (looking back). Namun pada penelitian ini akan dipilih model IDEAL oleh Bransford dan Stein, IDEAL mengindikatorkan kemampuan pemecahan masalah siswa menjadi lima, IDE $A L$ mengandung makna mengidentifikasikan masalah (I-Identify problem), menentukan tujuan (D-Define goal), mengeksplorasi strategi yang mungkin ( $E$ Explore possible strategies), melaksanakan strategi (A-Act on strategie), dan melihat kembali dan mengevaluasi hasilnya (L-Look back and evaluate the effects). Model IDEAL dipilih karena lebih terperinci tahapannya dibandingkan model lainnya. Berikut adalah faktor-faktor yang diduga dapat mempengaruhi kemampuan pemecahan masalah matematika dikenal dengan strategi IDE $A L$ [3].

\section{Identifikasi Masalah (Identify)}

Pertama dari IDEAL adalah secara sengaja (Intentionally) berusaha untuk mengidentifikasi (Identify) masalah dan menjadikannya sebagai kesempatan (opportunities) untuk melakukan sesuatu yang kreatif. Kemampuan untuk mengidentifikasi keberadaan masalah adalah satu karateristik penting untuk menunjang keberhasilan penyelesaian masalah. Jika masalah tidak diidentifikasi maka strategi yang mungkin digunakan tidak akan dapat ditemukan. Dengan kata lain dalam kegiatan pemecahan masalah ini siswa melakukan identifikasi terhadap persoalan yang diberikan, identifikasi yang dimaksud dapat berupa mendaftarkan data-data pada persoalan atau bahkan menghubungkan data-data yang diketahui [4].

\section{Menetukan Tujuan (Define)}

Kedua dari IDEAL adalah mengembangkan (Develop) pemahaman dari masalah yang telah diidentifikasi dan berusaha menentukan (Define) tujuan. Menentukan tujuan berbeda dengan mengidentifikasi masalah. Sebuah masalah yang ada tergantung pada bagaimana mereka menentukan tujuan, dan hal ini mempunyai efek yang penting terhadap tipe jawaban yang akan dicoba. Tujuan yang berbeda membuat orang mengeksporasi strategi yang berbeda untuk menyelesaikan masalah. Dengan kata lain dalam kegiatan ini siswa harus dapat menyaring segala informasi yang telah diketahui dan menganalisisnya untuk menentukan tujuan dari persoalan yang diberikan. Menentukan tujuan tidak kalah penting, sebab kesalahan dalam langkah ini akan berdampak pada hasil pemecahan masalahnya[4].

\section{Menentukan Strategi yang Mungkin (Explore)}

Ketiga dari IDEAL adalah mengeksplorasi (Explore) strategi yang mungkin dan mengevaluasi (Evaluate) kemungkinan strategi tersebut sesuai dengan tujuan yang telah ditetapkan. Beberapa strategi dalam penyelesaian masalah sangatlah umum dan dapat digunakan pada hampir semua masalah yang ada. Tapi beberapa strategi sangatlah khusus dan hanya digunakan pada kasus-kasus tertentu.

\section{Melaksanakn Strategi $(\boldsymbol{A c t})$}

Keempat dari IDEAL adalah mengantisipasi (Anticipate) hasil dan bertindak (Act). Ketika sebuah strategi dipilih, maka mengantisipasi kemungkinan hasil dan kemudian bertindak pada strategi yang dipilih. Mengantisipasi hasil yang akan berguna dari hal-hal akan disesali di kemudian hari. Dengan kata lain dalam kegiatan ini merupakan kelanjutan tahap sebelumnya yaitu melaksanakan strategi yang dipilih, sehingga persoalan dapat ditemukan jawabannya [4].

\section{Memeriksa Kembali (Look)}

Kelima dari IDEAL adalah melihat (Look) akibat yang nyata dari strategi yang digunakan dan belajar (Learn) dari pengalaman yang didapat. Melihat dan belajar perlu dilakukan karena setelah mendapatkan hasil, banyak yang lupa untuk melihat kembali dan belajar dari penyelesaian masalah yang telah dilakukan.

Dari pemaparan tersebut permasalahannya adalah apakah benar kelima faktor-faktor internal tersebut mempengaruhi kemampuan pemecahan masalah matematika, guru biasanya cenderung 
menyoroti faktor-faktor eksternal khususnya penggunaan metode pembelajaran di kelas, minim adanya pertimbangan mengenai faktor-faktor internal yang ikut berpengaruh serta yang paling dominan mempengaruhi kemampuan pemecahan masalah serta siswa juga kurang terbiasa melakukan tahapan pemecahan masalah dengan benar seperti mengidentifikasikan masalah (identify), menentukan tujuan masalah (define), menentukan strategi yang mungkin (explore), melaksanakan strategi (act), dan memeriksa kembali (look) sehingga mungkin dapat menyebabkan rendahnya kemampuan pemecahan masalah matematika.

Hal yang dilakukan untuk menjawab permasalahan tersebut dengan mengadakan tes pemecahan masalah yang menguji setiap kemampuan siswa dalam mengidentifikasikan masalah (identify), menentukan tujuan masalah (define), menentukan strategi yang mungkin (explore), melaksanakan strategi $(a c t)$, dan memeriksa kembali (look) sehingga nantinya dapat ditentukan apakah kelima faktor internal tersebut mempengaruhi kemampuan pemecahan masalah. Hal ini terkait dengan penelitian yang dilakukan oleh Ulya yang menyimpulkan kemampuan pemecahan masalah matematika tergolong baik dikarenakan sebagian besar indikator pemecahan masalah dapat dipenuhi dengan baik [5]. Selanjutnya terkait dengan hasil penelitian oleh Harahap yaitu kemampuan pemecahan masalah siswa yang tergolong dalam kemampuan sangat tinggi adalah subjek S1 dikarenakan memiliki kemampuan memahami masalah, kemampuan merencanakan pemecahan masalah, kemampuan pemecahan masalah dan kemampuan menafsirkan solusi dengan baik. Kemampuan pemecahan masalah siswa yang tergolong dalam kemampuan cukup adalah S2 dan S3. Dimana S2 tidak memahami konsep yang digunakan, tidak merencanakan penyelesaian masalah sehingga tidak menyelesaikan masalah dengan baik. Walaupun begitu S2 mampu menemukan solusi secara tepat. Sedangkan S3 memahami konsep apa yang digunakan untuk menyelesaikan permasalahan ini. Namun S3 tidak merencanakan pemecahan masalah, tidak menyelesaiakan masalah secara tepat dan menafsirkan solusi yang salah [6]. Dari kedua penelitian yang terkait tersebut disimpulkan adanya pengaruh mengidentifikasi masalah, menentukan tujuan masalah, memilih strategi yang mungkin, melaksanakan strategi, dan memeriksa kembali terhadap kemampuan pemecahan masalah. Dengan penelitian ini kita juga dapat melihat pengaruh faktor-faktor tersebut terhadap kemampuan pemecahan masalah. Kelebihan penelitian ini yaitu dapat melihat seberapa besar pengaruh faktor-faktor tersebut dan faktor apa yang paling dominan mempengaruhi kemampuan pemecahan masalah matematika.

Penelitian yang sejalan dengan ini tetapi memiliki hasil yang berbeda namun membuktikan adanya faktor internal lain yang dapat mempengaruhi kemampuan pemecahan masalah matematika, yaitu penelitian oleh (1) Irawan dkk yang menyimpulkan bahwa pengetahuan awal, apresiasi matematika, dan kecerdasan logis matematis dapat mempengaruhi kemampuan pemecahan masalah matematika [7]. (2) Kartika Handayani yang menyimpulkan faktor pengalaman, motivasi, kemampuan memahami masalah, dan ketrampilan berpikir mempengaruhi kemampuan pemecahan masalah matematika dengan faktor yang paling dominan adalah faktor ketrampilan berpikir [8]. Berdasarkan hal tersebut maka tujuan dari penelitian ini adalah 1) mengkaji faktor-faktor yang mempengaruhi kemampuan pemecahan masalah matematika dan (2) mengidentifikasi dominasi faktor-faktor yang mempengaruhi kemampuan pemecahan masalah matematika.

\section{METODE PENELITIAN}

Penelitian kuantitatif ini merupakan penelitian ex-post facto disebut demikian karena sesuai dengan pengertiannya yaitu "dari apa dikerjakan setelah kenyataan", maka penelitian ini disebut sebagai penelitian sesudah kejadian dan kemudian merunut kebelakang untuk mengetahui faktor-faktor yang dapat menyebabkan timbulnya kejadian tersebut [9]. Populasi dalam penelitian ini adalah seluruh siswa 
kelas VIII SMP Negeri di kota Singaraja pada tahun pelajaran 2017/2018, pengambilan sampel menggunakan stratified cluster random sampling. Oleh karena itu sampel yang terpilih dalam penelitian ini berjumlah 377 siswa dari 3 sekolah yaitu SMPN 1 Singaraja, SMPN 4 Singaraja dan SMPN 7 Singaraja.

Peneliti menggunakan rancangan korelasional didalam proses faktorial, tujuan dalam penelitian ini adalah untuk mencari hubungan interdependensi antar variabel agar dapat menggambarkan faktorfaktor yang mempengaruhi kemampuan pemecahan masalah matematika siswa. Desain penelitian tampak pada Gambar 1 berikut:

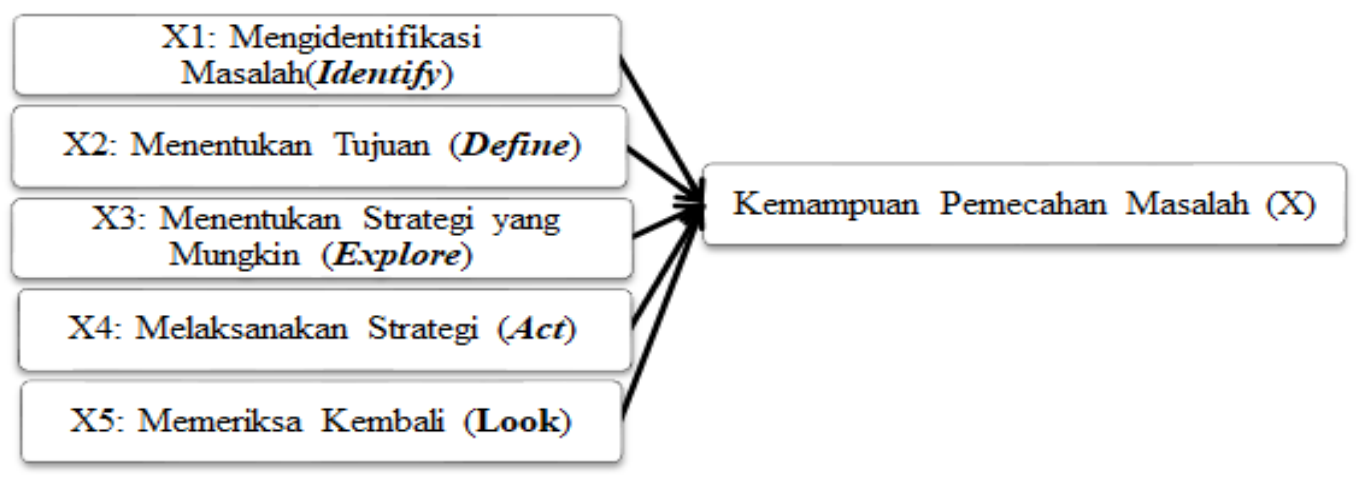

\section{Gambar 1. Desain Penelitian}

Jenis instrumen yang digunakan dalam penelitian ini berupa tes uraian soal cerita matematika. Data yang akan dikumpulkan pada penelitian ini adalah data mengidentifikasikan masalah (identify), data menentukan tujuan (define), data menentukan strategi yang mungkin (explore), data melaksanakan strategi (act), dan data memeriksa kembali (look).

Instrumen tes terdiri dari materi sistem persamaan linier dua variabel, teorema pythagoras dan lingkaran. Penyusunan instrumen penelitian dimulai dengan mengidentifikasi kompetensi dasar dan indikator yang akan dinilai, kemudian menyusun tes dan melakukan uji pakar oleh dua dosen Pendidikan Matematika Universitas Pendidikan Ganesha Singaraja dan empat guru kelas delapan sekolah menengah pertama. Uji coba dilaksanakan di SMP N 2 Singaraja. Banyak responden dalam pelaksanaan uji coba ini adalah 65 siswa kelas VIII SMP semester 2 tahun ajaran 2017/2018. Uji validitas isi atau uji pakar ini menggunakan teknik Lawshe's CVR atau Content Validity Ratio dengan perhitungan manual. Hasil dari uji pakar menunjukkan bahwa instrumen penelitian memiliki validitas isi sebesar 1,00 dengan kata lain seluruh soal dalam instrumen relevan digunakan ditinjau dari pandangan pakar. Instrumen yang telah diuji validitas isinya kemudian diuji cobakan kepada siswa. Uji coba instrumen dilakukan untuk memperoleh gambaran secara empirik bahwa tes pemecahan masalah matematika yang digunakan merupakan instrumen yang valid dan reliabel serta dapat digunakan dalam penelitian. Hasil uji coba instrumen dianalisis validitas dan reliabilitasnya. Uji validitas instrumen menggunakan koefisien korelasi product moment. Secara ringkas hasil perhitungan validitas butir instumen $r_{x y}$ yang dibandingkan dengan $r_{\text {tabel }}$ untuk jumlah sampel 65 dengan taraf signifikansi $\alpha=5 \%$ adalah 0,244. Proses perhitungan, disimpulkan bahwa dari 10 soal dengan 17 butir pertanyaan diperoleh 14 butir valid dan 3 butir yang tidak valid. Butir yang tidak valid adalah nomor 3a, 3b, dan 10b. Selanjutnya dilakukan uji reliabilitas instrumen menggunakan rumus Alpha Cronbach. Butir soal yang diuji reliabilitas hanya butir soal yang valid sehingga hanya 14 butir saja yang diuji reliabilitasnya. Hasil uji reliabilitas instrumen diperoleh derajat reliabilitasnya sebesar 0,711 yang tergolong dalam kategori reliabilitas tinggi. Dari 14 butir yang valid dan reliabel valid akan digunakan 10 butir yaitu soal nomor 1a, 1b, 2a, 2b, 4a, 4b, 5a, 5b, 8 dan 9 dalam penelitian. 


\section{HASIL DAN PEMBAHASAN}

Dalam melakukan identifikasi terhadap faktor-faktor yang mempengaruhi kemampuan pemecahan masalah matematika digunakan software SPSS 20.0. Hal pertama yang dilakukan adalah melakukan analisis deskriptif kemudian dilakukan analisis faktor. Berikut hasil jumlah keseluruhan sampai dengan standar deviasi masing-masing variabel IDEAL pada Tabel 1.

Tabel 1 Ringkasan Hasil Perhitungan Statistik Data Penelitian

\begin{tabular}{cccccc}
\hline & $\mathrm{I}$ & $\mathrm{D}$ & $\mathrm{E}$ & $\mathrm{A}$ & $\mathrm{L}$ \\
\hline Jumlah & 2828 & 1806 & 1820 & 1615 & 1987 \\
Rata-rata & 7,5 & 4,79 & 4,83 & 4,28 & 5,27 \\
Median & 8 & 5 & 4 & 4 & 5 \\
Modus & 8 & 6 & 4 & 2 & 5 \\
Maksimum & 10 & 10 & 10 & 10 & 10 \\
Minimum & 2 & 2 & 2 & 2 & 3 \\
Jangkauan & 8 & 8 & 8 & 8 & 7 \\
Standar Deviasi & 1,67 & 2,04 & 2,18 & 2,02 & 1,08 \\
\hline
\end{tabular}

Selanjutnya dilakukan uji asumsi kelayakan data, sebelumnya analisis faktor pada SPSS menghasilkan matriks korelasi, Bartlett's Sphericity dan KMO

Tabel 2 Matriks Korelasi

\begin{tabular}{rrrrrrr}
\hline & \multicolumn{2}{c}{$\mathrm{D}$} & \multicolumn{2}{l}{$\mathrm{E}$} & $\mathrm{L}$ & \\
\hline $\mathrm{I}$ & 1 & 0,35 & 0,04 & 0,06 & 0,12 \\
\hline $\mathrm{D}$ & 0,35 & 1 & 0,37 & 0,33 & 0,2 \\
\hline $\mathrm{E}$ & 0,04 & 0,37 & 1 & 0,85 & 0,33 \\
\hline $\mathrm{A}$ & 0,06 & 0,33 & 0,85 & 1 & 0,36 \\
\hline $\mathrm{L}$ & 0,12 & 0,2 & 0,33 & 0,36 & 1 \\
\hline
\end{tabular}

Tabel 3 KMO and Bartlett's Test

\begin{tabular}{lll}
\hline $\begin{array}{l}\text { Kaiser-Meyer-Olkin Measure of } \\
\text { Sampling Adequacy. }\end{array}$ & 0,619 \\
\hline \multirow{3}{*}{ Bartlett's Test of Sphericity } & \begin{tabular}{l} 
Approx. \\
\cline { 2 - 3 }
\end{tabular} & Chi-Square \\
\cline { 2 - 3 } & Sf & 640,28 \\
\cline { 2 - 3 } & Sig. & 0,000 \\
\hline
\end{tabular}

Dari hasil Tabel 2 terlihat nilai korelasi antar variabelnya misalnya korelasi variabel I dan D adalah 0,35 yang artinya nilai korelasi antara mengidentifikasi masalah (identify) dengan menentukan tujuan masalah (define) adalah 0,35, dst. Selanjutnya matriks korelasi tersebut digunakan untuk menguji asumsi apakah dapat digunakan analisis faktor atau tidak, ada tiga hal yang perlu dilakukan yaitu Uji Bartlett's Sphericity, KMO dan MSA. Pada Tabel 3 diperoleh nilai Bartlett's test of sphericity diperoleh hasil sig (level of significance) sebesar 0,000 hal ini mengidentifikasikan bahwa matriks korelasi antar variabel tidak sama dengan matriks identitas atau dengan kata lain ada korelasi antar variabel. Nilai KMO sebesar 0,619 dimana nilai tersebut lebih besar dari 0,5. Dengan demikian dapat disimpulkan bahwa asumsi kecukupan data telah terpenuhi dengan kategori cukup memuaskan. Selanjutnya dengan uji MSA, hasilnya pada Tabel 4. 
Numerical: Jurnal Matematika dan Pendidikan Matematika, Vol. 2 No. 2 Desember 2018, 153-166

Ni Komang Vonie Dwianjani, I Made Candiasa, Sariyasa

Tabel 4 Uji MSA (Anti-image Correlation)

\begin{tabular}{llllll}
\hline & $\mathrm{I}$ & $\mathrm{D}$ & $\mathrm{E}$ & $\mathrm{A}$ & $\mathrm{L}$ \\
\hline $\mathrm{I}$ & $\mathbf{0 , 5 1 0 ^ { \mathbf { a } }}$ & $-0,35$ & 0,081 & $-0,02$ & $-0,08$ \\
\hline $\mathrm{D}$ & $-0,35$ & $\mathbf{0 , 7 1 9}$ & $-0,182$ & $-0,02$ & $-0,05$ \\
\hline $\mathrm{E}$ & 0,081 & $-0,182$ & $\mathbf{0 , 5 8 0 ^ { \mathbf { a } }}$ & $-0,81$ & $-0,05$ \\
\hline $\mathrm{A}$ & $-0,016$ & $-0,022$ & $-0,81$ & $\mathbf{0 , 5 8 6 ^ { \mathbf { a } }}$ & $-0,15$ \\
\hline $\mathrm{L}$ & $-0,083$ & $-0,051$ & $-0,046$ & $-0,15$ & $\mathbf{0 . 8 9 \mathbf { 6 } ^ { \mathbf { a } }}$ \\
\hline
\end{tabular}

Pada tabel 4 tampak bilangan-bilangan diagonal dari sisi kiri atas ke kanan bawah berlabel a dibelakangnya, bilangan tersebut merupakan koefesien MSA, selanjutnya semua variabel butir memiliki MSA > 0,5 maka variabel masih bisa diprediksi dan dianalis lebih lanjut serta semua variabel tidak ada yang harus dieleminasi. Metode yang digunakan analisis komponen utama PCA (principal component analysis) berikut hasilnya dilihat pada Tabel 5 .

Tabel 5 Nilai Eigenvalue \& Varian Komulatif

\begin{tabular}{|c|c|c|c|c|c|}
\hline \multirow{2}{*}{ Component } & \multicolumn{3}{|c|}{ Initial Eigenvalues } & \multicolumn{2}{|c|}{ Extraction Sums of Squared Loadings } \\
\hline & Total & $\begin{array}{l}\% \text { of } \\
\text { Variance }\end{array}$ & Cumulative $\%$ & Total & $\%$ of Variance Cumulative $\%$ \\
\hline 1 & 2,337 & 46,746 & 46,746 & 2,337 & 46,746 \\
\hline 2 & 1,162 & 23,232 & 69,978 & 1,162 & 69,978 \\
\hline 3 & 0,788 & 15,769 & 85,747 & & \\
\hline 4 & 0,563 & 11,266 & 97,013 & & \\
\hline 5 & 0,149 & 2,987 & 100,000 & & \\
\hline
\end{tabular}

Pada tabel 5 menunjukan banyaknya komponen yang terbentuk adalah 2 komponen karena nilai eigenvalue yang lebih besar dari 1 hanya 2,337 dan 1,162. Hal ini diperjelas dengan hasil Scree Plot pada Gambar 2, menunjukan hal yang sama dimana titik yang merupakan panggal garis mengalami penurunan paling tajam berada pada komponen 2 .

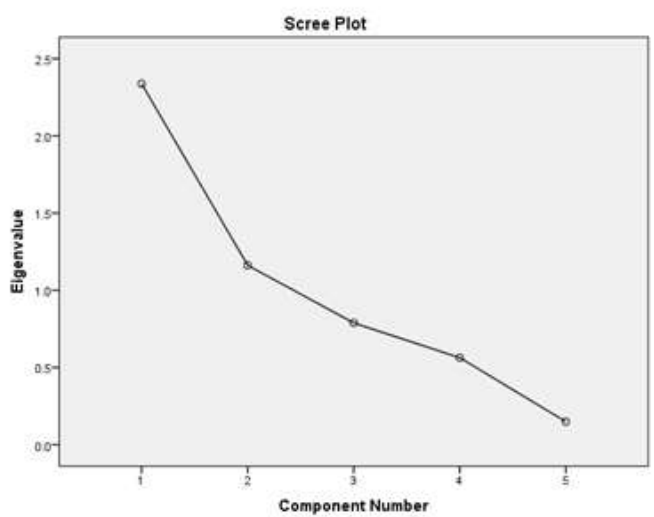

Gambar 2. Grafik Nilai Eigenvalue 
Berdasarkan hal tersebut dapat disimpulkan kelima variabel tersebut mempengaruhi kemampuan pemecahan masalah matematika yang dikelompokan menjadi 2 komponen utama yang merupakan representasi dari kelima variabel yang ada. Hal itu diperjelas dengan total nilai percentage of variance dua komponen tersebut sebesar 69,978\%. Dengan kata lain dua komponen yang terdiri dari variabel-variabel mengidentifikasi masalah (I), menentukan tujuan masalah (D), memilih strategi yang mungkin (E), melaksanakan strategi (A), dan memeriksa kembali (L) mampu menjelaskan pengaruhnya sebesar 69,978\% terhadap kemampuan pemecahan masalah matematika atau hanya 30,022\% variasi dimensi atau komponen yang mempengaruhi kemampuan pemecahan masalah matematika yang tidak tergambarkan oleh kedua komponen tersebut. Sebelumnya analisis faktor juga menghasilkan nilai komunalitas yang menjelaskan sumbangan masing-masing variabel terhadap komponen bersamanya.

Tabel 6. Nilai Komunalitas

\begin{tabular}{ccc}
\hline & Initial & Extraction \\
\hline I & 1,000 & 0,809 \\
\hline D & 1,000 & 0,631 \\
\hline E & 1,000 & 0,863 \\
\hline A & 1,000 & 0,865 \\
\hline L & 1,000 & 0,331 \\
\hline
\end{tabular}

Extraction Method: Principal Component Analysis.

Dari tabel 6 diketahui bahwa peranan dimensi yang terbesar adalah variabel A sebesar 0,865 atau sebesar 86,5\% proporsi keragaman variabel A yang dapat dijelaskan oleh kedua komponen. Hasil tersebut dapat menjelaskan bahwa melaksanakan strategi $(A c t)$ merupakan faktor yang paling dominan mempengaruhi kemampuan pemecahan masalah matematika, selanjutnya disusul oleh faktor menentukan strategi yang mungkin (explore), mengidentifikasikan masalah (identify) menentukan tujuan (define) dan memeriksa kembali (look). Selanjutnya setelah diketahui kelima variabel dapat dikelompokkan menjadi 2 komponen utama maka selanjutnya dilakukan pengelompokan variabel kedalam komponen tertentu berdasarkan factor loading yang menunjukan besarnya korelasi antara suatu variabel dengan komponen pembentuknya.

Tabel 7 Komponen Matriks

\begin{tabular}{ccc}
\hline & \multicolumn{2}{c}{ Component } \\
\cline { 2 - 3 } & 1 & 2 \\
\hline $\mathrm{I}$ & 0,282 & 0,854 \\
\hline $\mathrm{D}$ & 0,619 & 0,498 \\
\hline $\mathrm{E}$ & 0,879 & $-0,300$ \\
\hline $\mathrm{A}$ & 0,879 & $-0,305$ \\
\hline $\mathrm{L}$ & 0,575 & $-0,031$ \\
\hline
\end{tabular}

Extraction Method: Principal Component Analysis

a. 2 components extracted
Tabel 8 Rotasi Komponen Matriks

\begin{tabular}{ccc}
\hline & \multicolumn{2}{c}{ Component } \\
\cline { 2 - 3 } & 1 & 2 \\
\hline $\mathrm{I}$ & $-0,061$ & 0,898 \\
\hline $\mathrm{D}$ & 0,385 & 0,695 \\
\hline $\mathrm{E}$ & 0,927 & 0,053 \\
\hline $\mathrm{A}$ & 0,929 & 0,049 \\
\hline $\mathrm{L}$ & 0,544 & 0,188 \\
\hline
\end{tabular}

Extraction Method: Principal Component Analysis.

Rotation Method: Varimax with Kaiser Normalization.

a. Rotation converged in 3 iterations.

Sebelum pengelompokan variabel ke dalam komponen, dilakukan rotasi yang bertujuan untuk mendapatkan factor loading yang cukup jelas untuk diinterpretasikan. Pada SPSS di jelaskan pada tabel 8 
yang merupakan matriks korelasi yang memperlihatkan distribusi variabel yang lebih jelas dan nyata dibandingkan dengan tabel 7. Dari hasil tabel 8 kelima variabel dapat dikelompokan menjadi dua komponen utama. I masuk ke dalam komponen 2 karena koefesien korelasi terbesarnya 0,898; D masuk ke dalam komponen 2 karena koefesien korelasi terbesarnya 0,695; E masuk ke dalam komponen 1 karena koefesien korelasi terbesarnya 0,927; A masuk ke dalam komponen 1 karena koefesien korelasi terbesarnya 0,929; L masuk ke dalam komponen 1 karena koefesien korelasi terbesarnya 0,544. Setelah didapat hasil pengelompokan variabel selanjutnya penamaan. Dengan melakukan generalisasi selanjutnya komponen 1 dinamakan komponen kemampuan sistematis, dan komponen 2 dinamakan komponen kemampuan analitis. Kemampuan sistematis memiliki arti kemampuan untuk mengerjakan sesuatu sesuai dengan urutan, tahapan, langkah-langkah, atau perencanaan yang tepat, efektif, dan efesien sedangkan kemampuan analitis memiliki arti kemampuan untuk merinci atau menguraikan suatu masalah menjadi bagian-bagian yang perlu serta mampu memahami hubungan diantara bagian-bagian tersebut [10]

Hasil penelitian menunjukan bahwa analisis faktor telah sampai ke pembentukan komponenkomponen utama, maka secara langsung variabel-variabel tersebut berpengaruh terhadap kemampuan pemecahan masalah. Hasil penelitian disimpulkan bahwa mengidentifikasi masalah (identify), menentukan tujuan masalah (define), memilih strategi yang mungkin (explore), melaksanakan strategi (act), dan memeriksa kembali (look) mempengaruhi kemampuan pemecahan masalah matematika yang dikelompokan menjadi 2 komponen utama yang merupakan representasi dari kelima variabel yang ada. Hal itu diperjelas dengan total nilai percentage of variance dua komponen tersebut sebesar 69,978\%. Dengan kata lain dua komponen yang terdiri dari variabel-variabel mengidentifikasi masalah (identify), menentukan tujuan masalah (define), memilih strategi yang mungkin (explore), melaksanakan strategi (act), dan memeriksa kembali (look) mampu menjelaskan pengaruhnya sebesar 69,978\% terhadap kemampuan pemecahan masalah matematika.

Hasil penelitian ini sesuai dengan teori yang dinyatakan oleh Bransford and Stein yang menyatakan bahwa IDEAL merupakan indikator untuk mengukur kemampuan pemecahan masalah atau dengan kata lain faktor mengidentifikasi masalah (identify), menentukan tujuan masalah (define), memilih strategi yang mungkin (explore), melaksanakan strategi (act), dan memeriksa kembali (look) mempengaruhi kemampuan pemecahan masalah matematika. Hasil penelian ini menyimpulkan hal yang sama walaupun terdapat perbedaan dan batasan-batasan tertentu seperti metode penelitian, lokasi penelitian, materi yang diujikan, situasi dan karakter siswa yang berbeda-beda sebagai populasi.

Masing-masing pembahasan IDEAL akan dijelaskan sebagai berikut. Pertama mengidentifikasi masalah (Identify), terbukti memiliki pengaruh terhadap kemampuan pemecahan masalah matematika, mengidentifikasi masalah akan mempengaruhi tingkat kemampuan pemecahan masalah matematika. Selain itu mengidentifikasikan masalah terbukti memiliki korelasi terhadap variabel lainnya, analisis faktor merupakan teknik analisis ketergantungan, maka dari itu identify terbukti memiliki hubungan terhadap variabel-variabel lainnya atau satu set hubungan dengan variabel lainnya untuk mempengaruhi kemampuan pemecahan masalah matematika. Hubungan korelasi antar variabel dapat dilihat dari nilai bartlett's test of sphericity diperoleh hasil sig (level of significance) sebesar 0,000 hal ini mengidentifikasikan bahwa ada korelasi dengan variabel lainnya.

Mengidentifikasikan masalah (Identify) adalah suatu hal yang penting dilakukan untuk memecahkan suatu masalah, dengan mengidentifikasi masalah siswa akan lebih mudah menganalisis maksud soal dan menentukan pemecahannya dengan benar. Mengidentifikasi masalah adalah suatu kegiatan berupa mendaftarkan data-data pada persoalan atau bahkan menghubungkan data-data yang diketahui. Mengidentifikasi masalah dalam hal ini yaitu menuliskan pernyataan-pernyataan yang 
diketahui dan yang ditanyakan pada soal. Mengidentifikasi masalah matematika penting dilakukan khususnya pada soal uraian berbentuk cerita. Mengidentifikasikan masalah pada IDEAL Problem solving sama halnya dengan memahami masalah pada pemecahan masalah [11].

Mengidentifikasikan masalah yang disertai dengan menentukan tujuan masalah, memilih strategi yang tepat, melaksanakan strategi serta memeriksa kembali merupakan langkah-langkah yang dapat diurut untuk melakukan kegiatan menyelesaikan suatu masalah matematika. Kelima teknik IDEAL tersebut dilakukan bersamaan dan terurut karena telah terbukti memiliki pengaruh terhadap kemampuan pemecahan masalah, kemampuan IDEAL yang dimiliki siswa akan dapat mempengaruhi tingkat kemampuan pemecahan masalah matematika siswa. Terdapat hubungan mengidentifikasikan masalah dengan menentukan tujuan masalah yaitu dengan contoh saat siswa dapat menyaring segala informasi dari apa yang diketahui dan ditanyakan pada soal selanjutnya siswa akan lebih mudah menentukan tujuan dari persoalan yang diberikan karena akan ada bayangan tentang konsep apa yang digunakan atau dituju dari apa yang ditanyakan dan diketahui oleh soal tersebut begitu juga sebaliknya. Terdapat hubungan mengidentifikasikan masalah dengan memilih strategi yang mungkin yaitu dengan contoh saat siswa dapat mendaftarkan apa yag diketahui dan ditanyakan maka siswa akan lebih mudah untuk memilih strategi apa digunakan untuk masalah yang ditanyakan. Terdapat hubungan antara mengidentifikasikan masalah dengan melaksanakan strategi yaitu dengan contoh saat siswa dapat mengidentifikasikan masalah maka siswa akan lebih mudah melaksanakan rencana sesuai dengan rencana strategi. Terdapat hubungan antara mengidentifikasikan masalah dengan memeriksa kembali yaitu dengan contoh saat siswa dapat mengidentifikasikan masalah maka siswa akan lebih mudah memeriksa kembali solusi masalah dengan mencocokan hasil dengan apa yang ditanyakan dan diketahui begitu sebaliknya.

Bransford \& Stein menyatakan mengidentifikasikan masalah (identify) merupakan langkah pertama dari IDEAL yaitu secara sengaja (Intentionally) berusaha untuk mengidentifikasi (identify) masalah dan menjadikannya sebagai kesempatan (opportunities) untuk melakukan sesuatu yang kreatif. Kemampuan untuk mengidentifikasi masalah adalah satu karateristik penting untuk menunjang keberhasilan penyelesaian masalah. Jika masalah tidak diidentifikasi maka strategi yang mungkin digunakan tidak akan dapat ditemukan. Mengidentifikasikan masalah (identify) setelah dilakukan analisis faktor dikelompokan kedalam kelompok 2 dengan pemberian nama komponen kemampuan analitis bersama dengan variabel menentukan tujuan masalah (define).

Kedua menentukan tujuan masalah (define). Define terbukti memiliki pengaruh terhadap kemampuan pemecahan masalah matematika, dengan menentukan tujuan masalah (define) maka mempengaruhi tingkat kemampuan pemcahan masalah matematika, sebagai contoh dengan mengetahui konsep apa yang digunakan maka akan lebih mudah dalam memecahkan masalah yang diberikan. Menentukan tujuan masalah (define) adalah kegiatan untuk menyaring segala informasi yang telah diketahui dan menganalisisnya untuk mennetukan tujuan dari persoalan yang diberikan. Menentukan tujuan masalah dalam penelitian ini yaitu menuliskan konsep apa yang digunakan dalam memecahkan masalah, saat siswa mampu menyebutkan konsep yang digunakan maka tujuan diberikan soal terlaksana sehingga akan lebih mudah memecahkan suatu masalah.

Selain itu Define terbuti memiliki hubungan terhadap variabel-variabel lainnya atau satu set hubungan yang erat dengan variabel lainnya untuk mempengaruhi kemampuan pemecahan masalah matematika. Hubungan korelasi antar variabel dapat dilihat dari nilai bartlett's test of sphericity diperoleh hasil sig (level of significance) sebesar 0,000 hal ini mengidentifikasikan bahwa ada korelasi antar variabelnya. Menentukan tujuan masalah yang disertai dengan mmengidentifikasikan masalah, memilih strategi yang tepat, melaksanakan strategi serta memeriksa kembali terbukti memiliki pengaruh terhadap 
kemampuan pemecahan masalah. Selain itu terdapat hubungan antara menentukan tujuan masalah dengan mengidentifikasikan masalah yang telah dijelaskan sebelumnya, selanjutnya terdapat hubungan antara menentukan tujuan masalah atau menentukan konsep dengan pemilihan strategi yang mungkin yaitu saat siswa mampu menentukan konsep apa yang digunakan maka semakin mudah mentukan langkah-langkah apa yang harus dilakukan untuk menemukan solusi yang tepat sesuai dengan tujuan dan maksud soal. Terdapat hubungan antara menentukan konsep dengan melaksanakan strategi, saat siswa dapat menentukan konsep apa yang digunakan maka pelaksanaan strategi seharusnya dilaksanakan berdasarkan konsep-konsep yang ada dalam suatu materi, misalnya yaitu soal dengan tujuan atau konsep sistem persamaan linier dua variabel maka akan lebih mudah melaksanakan strategi berdasarkan konsep-konsep yang ada pada sistem persamaan dua variabel misalnya dengan konsep substitusi, eliminasi ataupun grafik. Terdapat hubungan antara menentukan konsep dengan memeriksa kembali atau evaluasi, dengan memahani atau menetukan konsep maka memeriksa kembali akan lebih mudah yaitu dengan melihat dasar-dasar konsep, misalkan memeriksa kembali jawaban soal lingkaran yang didasarkan dengan rumus-rumus dan konsep-konsep pada lingkaran seperti luas atau keliling lingkaran, hal tersebut berlaku sebaliknya.

Ketiga memilih strategi yang mungkin (Explore) terbukti memiliki pengaruh terhadap kemampuan pemecahan masalah matematika, misalnya saat mampu mengeksplorasi strategi serta memilih strategi dengan banar maka akan lebih mudah dalam memecahkan masalah matematika karena telah disusun rencana-rencana apa yang digunakan untuk memecahkan masalah. Selain itu explore terbukti memiliki hubungan terhadap variabel-variabel lainnya untuk mempengaruhi kemampuan pemecahan masalah matematika. Explore adalah kegiatan untuk menyeleksi strategi yang cocok yang digunakan untuk memecahkan masalah. Memilih strategi yang mungkin (explore) dalam penelitian yaitu menuliskan langkah-langkah secara terurut untuk memecahkan masalah. Explore atau kegiatan memilih strategi yang mungkin, yang disertai dengan menentukan tujuan masalah, mmengidentifikasikan masalah, melaksanakan strategi, dan memeriksa kembali terbukti memiliki pengaruh terhadap kemampuan pemecahan masalah. Terdapat hubungan antara explore strategi dengan mengidentifikasikan masalah dan menentukan tujuan yang sudah dibahas sebelumnya selanjutnya terdapat hungungan mengeksplor strategi terhadap melaksanakan strategi yaitu contohnya saat siswa dapat menulis langkahlangkah strategi maka akan lebih mudah memecahkan masalah yang dilakukan tahap demi tahap rencana yang sudah ditetapkan. Terdapat hubungan antara merencanakan strategi dengan memeriksa kembali, saat siswa dapat mengurutkan langkah-langkah pemecahan masalah maka dengan mudah memeriksa kembali pemecahan masalah hanya tinggal melihat langkah-langkahnya sesuai tidaknya dengan rencana yang sudah ditentukan, begitu juga sebaliknya. Explore merupakan langkah ketiga dari IDEAL yaitu mengeksplorasi (explore) strategi yang mungkin dan mengevaluasi (evaluate) kemungkinan strategi tersebut sesuai dengan tujuan yang telah ditetapkan. Beberapa strategi dalam penyelesaian masalah sangatlah umum dan dapat digunakan pada hampir semua masalah yang ada. Tapi beberapa strategi sangatlah khusus dan hanya digunakan pada kasus-kasus tertentu [3]. Explore dan variabel sisanya setelah dilakukan analisis faktor dikelompokan kedalam kelompok 1 dengan pemberian nama komponen kemampuan sistematis.

Keempat melaksanakan strategi (act) terbukti memiliki pengaruh terhadap kemampuan pemecahan masalah matematika, hal ini dicontohkan saat siswa melaksanakan strategi dengan benar maka mampu memecahkan masalah dengan benar juga. Melaksanakan strategi (act) juga terbukti memiliki hubungan terhadap variabel-variabel lainnya untuk mempengaruhi kemampuan pemecahan masalah matematika. Hubungan korelasi antar variabel dapat dilihat dari nilai bartlett's test of sphericity diperoleh hasil sig (level of significance) sebesar 0,000 hal ini mengidentifikasikan bahwa ada korelasi antar 
variabelnya. Act on the strategies atau kegiatan melaksanakan strategi yang disertai dengan menentukan tujuan masalah, mengidentifikasikan masalah, merencanakan strategi, dan memeriksa kembali terbukti memiliki pengaruh terhadap kemampuan pemecahan masalah. Terdapat hubungan antara melaksanakan strategi dengan mengidentifikasikan masalah, menentukan tujuan, mengeksplorasi strategi yang sudah dibahas sebelumnya selanjutnya terdapat hungungan melaksanakan strategi dengan memeriksa kembali yaitu saat siswa dapat melaksanakan strategi barulah mampu memeriksa kembali, memeriksa apakah pelaksanaan strategi sudah tepat dengan rencana, konsep, dan perhitungan yang benar, sebaliknya jika siswa sudah mampu memeriksa kembali artinya sudah mampu mengevaluasi pelaksaan rencana yang sudah dirumuskan sebelumnya. Langkah keempat dari IDEAL adalah mengantisipasi (anticipate) hasil dan bertindak (act). ketika sebuah strategi dipilih, maka mengantisipasi kemungkinan hasil dan kemudian bertindak pada strategi yang dipilih. Mengantisipasi hasil yang akan berguna dari hal-hal akan disesali di kemudian hari [3].

Kelima memeriksa kembali (look) terbukti memiliki pengaruh terhadap kemampuan pemecahan masalah matematika yang artinya memeriksa kembali mempengaruhi tingkat kemampuan pemecahan masalah matematika. Selain itu memeriksa kembali juga terbukti memiliki hubungan terhadap variabelvariabel lainnya untuk mempengaruhi kemampuan pemecahan masalah matematika. Hubungan korelasi antar variabel dapat dilihat dari nilai bartlett's test of sphericity diperoleh hasil sig (level of significance) sebesar 0,000 hal ini mengidentifikasikan bahwa ada korelasi antar variabelnya. Look adalah kegiatan untuk melihat kembali dan mengevaluasi dari efek pekerjaan persoalan, tahap ini perlu dilakukan guna mengoreksi kembali atas apa yang telah siswa kerjakan dan mengevaluasi kebenaran uraian jawaban dari masalah yang diberikan. Look atau kegiatan memeriksa kembali yang disertai dengan mengidentifikasikan masalah, menentukan tujuan masalah, mengeksporasi strategi, dan melaksanakan strategi terbukti memiliki pengaruh terhadap kemampuan pemecahan masalah. Terdapat hubungan antara look dengan mengidentifikasikan masalah, menentukan tujuan, merencanakan strategi, dan melaksanakan strategi yang sudah dibahas sebelumnya.

Langkah terakhir dari IDEAL adalah melihat (look) akibat yang nyata dari strategi yang digunakan dan belajar (learn) dari pengalaman yang didapat. Melihat dan belajar perlu dilakukan karena setelah mendapatkan hasil, banyak yang lupa untuk melihat kembali dan belajar dari penyelesaian masalah yang telah dilakukan. Tidak semua permasalahan dapat diselesaikan dalam satu kali langkah pengerjaan. Adakalanya jawaban yang didapat tidak sesuai dengan tujuan yang ditetapkan. Dalam IDEAL problem solving jika dari langkah kelima yaitu melihat kembali (look back) jawaban yang ada ternyata tidak sesuai dengan tujuan diinginkan belum tercapai maka tahap dalam penyelesaian masalah dapat kembali ke tahap yang diperkirakan terjadi kesalahan [3].

Hasil analisis faktor menunjukan bahwa dari kelima faktor yang mempengaruhi kemampuan pemecahan masalah, melaksanakn strategi (act) merupakan yang paling dominan mempengaruhi kemampuan pemecahan masalah matematika. Hal ini dilihat dari nilai communalities atau komunalitias yang merupakan ukuran persentase varians variabel yang dijelaskan oleh sejumlah komponen bersama, semakin besar nilai komunalitasnya semakin besar korelasinya. Dari tabel communalities diketahui bahwa peranan variabel terbesar adalah melaksanakan strategi (act) dengan nilai sebesar 0.865 atau 86.5\% selanjutnya disusul oleh faktor menentukan strategi yang mungkin (explore) sebesar 86,3\%, mengidentifikasikan masalah (identify) sebesar 80,9\%, menentukan tujuan (define) sebesar 63,1\%, dan memeriksa kembali (look) sebesar 33,1\%.

Melaksanakan strategi (act) merupakan kegiatan penting yang memiliki pengaruh paling tinggi terhadap kemampuan pemecahan masalah matematika. Dalam menyelesaikan masalah matematika biasanya jawaban dari apa yang ditanyakan akan terlihat pada tahap ini, pada tahap ini juga pengetahuan 
siswa terkait konsep, rumus-rumus dan perhitungan kalkulasi siswa diuji untuk mengerjakan agar dapat menemukan solusi penyelesaian masalah dengan benar. Salah satu contoh melaksanakan strategi (act) dapat menjadi yang paling berpengaruh adalah saat diberikan soal pemecahan masalah siswa terkadang kurang terbiasa menyelesaikan secara bertahap yang dimana langsung menjawab dengan menulis "Jawaban" pada lembar jawaban yang menyimbolkan pelaksanaan strategi sedangkan tahap yang lain tidak dituliskan. Hal tersebut dinyatakan menjadi faktor utama penyebab kesalahan siswa memecahkan masalah matematika yaitu rendahnya ketrampilan siswa dalam melakukan perhitungan matematis dalam melaksanakan strategi, faktor utama penyebab kesalahan adalah siswa tidak terbiasa mengerjakan soal matematika menggunakan langkah secara terurut [12].

Melaksanakan strategi terbukti paling dominan mempengaruhi kemampuan pemecahan masalah matematika namun terkadang digunakan siswa secara langsung tanpa membuat langkah-langkah penyelesaian soal yang benar yang tidak didahului dengan mengidentifikasikan masalah, menentukan tujuan masalah, memilih strategi yang mungkin, melaksanakan strategi sampai pemeriksaan kembali penyelesaian, hal tersebut kurang efektif untuk meningkatkan kemampuan pemecahan masalah siswa. Salah satu contohnya penelitian yang mendukung pernyataan tersebut adalah tentang kemampuan pemecahan masalah PISA, salah satu faktor penyebab dari rendahnya kemampuan siswa dalam memecahkan masalah PISA adalah siswa kurang terbiasa melakukan proses pemecahan masalah dengan benar [2].

\section{SIMPULAN DAN SARAN}

Berdasarkan hasil penelitian dan pembahaan dapat disimpulkan sebagai berikut: (1) Faktorfaktor yang mempengaruhi kemampuan pemecahan masalah matematika adalah mengidentifikasi masalah (identify), menentukan tujuan masalah (define), memilih strategi yang mungkin (explore), melaksanakan strategi (act), dan memeriksa kembali (look). (2) Faktor yang paling dominan mempengaruhi kemampuan pemecahan masalah matematika adalah melaksanakn strategi (act), selanjutnya diikuti oleh faktor menentukan strategi yang mungkin (explore), mengidentifikasikan masalah (identify) menentukan tujuan (define) dan memeriksa kembali (look).

Kelima faktor tersebut dapat dikelompokkan menjadi dua, yaitu komponen kemampuan analitis yang terdiri dari mengidentifikasikan masalah dan menentukan tujuan serta komponen kemampuan sistematis yang terdiri dari menentukan strategi yang mungkin, melaksankan strategi dan memeriksa kembali.

Disarankan kepada guru dalam melaksanakan proses pembelajaran matematika hendaknya melihat faktor-faktor yang turut mempengaruhi kemampuan pemecahan masalah seperti mengidentifikasi masalah (identify), menentukan tujuan masalah (define), memilih strategi yang mungkin (explore), melaksanakan strategi (act), dan memeriksa kembali (look) yang secara bersama-sama sebagai langkah-langkah pemecahan untuk meningkatkan kemampuan pemecahan masalah. Guru juga hendaknya mampu mendesain kegiatan pembelajaran misalnya dengan memberikan soal-soal non rutin yang dituntun tahap-tahap pemecahannya menggunakan IDEAL Problem Solving. Disarankan kepada siswa agar mampu meningkatkan kemampuan pemecahan masalah matematika dengan gigih dan ulet melatih soal-soal pemecahan masalah agar terbiasa melakukan tahapan pemecahan masalah dengan benar yaitu salah satunya dengan tahapan IDEAL problem solving. Kepada peneliti lain, peneliti merasa bahwa masih banyak kekurangan sehingga perlu dilakukan penelitian lebih lanjut untuk membuktikan hasil penelitian ini. Hal yang menurut peneliti perlu dilakukan kajian lebih lanjut adalah penelitian selanjutnya dapat dilakukan diluar wilayah kota Singaraja, agar memperoleh informasi yang bervariasi, lebih akurat, dan dapat dilakukan penarikan kesimpulan secara umum pada wilayah yang berbeda. 


\section{DAFTAR PUSTAKA}

[1] Depdiknas, Peraturan Pemerintab RI No 22 Tahun 2006 tentang Standar Nasional Pendidikan. Jakarta: Cemerlang, 2006.

[2] S. Wardhani and Rumiati, Instrumen Penilaian Hasil Belajar Matematika SMP: Belajar dari PISA dan TIMSS. Yogyakarta: Pusat Pengembangan dan Pemberdayaan Pendidik dan Tenaga Kependidikan (PPPPTK) Matematika, 2011.

[3] J. Bransford and B. S. Stein, The Ideal Problem Solver: A Guide for Improving Thinking, Learning, and Creativity, 2nd ed. New York: W.H. Freeman, 1993.

[4] S. Brookhart, How To Assess Higher-order Thinking Skills In Your Classroom. Alexandria, VA: ASCD, 2010.

[5] H. Ulya, "Profil Kemampuan Pemecahan Masalah Siswa Bermotivasi Belajar Tinggi Berdasarkan IDEAL Problem Solving," Jurnal Konseling Gusjigang, vol. 2, no. 1, Aug. 2016.

[6] E. R. Harahap and E. Surya, "Kemampuan Pemecahan Masalah Matematis Siswa Kelas VII Dalam Menyelesaikan Persamaan Linear Satu Variabel,” p. 12, 2017.

[7] I. P. E. Irawan, I. G. P. Suharta, and I. N. Suparta, "Faktor-Faktor Yang Mempengaruhi Kemampuan Pemecahan Masalah Matematika: Pengetahuan Awal, Apresiasi Matematika, Dan Kecerdasan Logis Matematis,” p. 5, 2016.

[8] K. Handayani, "Analisis Faktor-Faktor yang Mempengaruhi Kemampuan Pemecahan Masalah Soal Cerita Matematika," 2017.

[9] Sukardi, Metologi Penelitian Pendidikan. Jakarta: PT Bumi Aksara, 2012.

[10] E. Suherman and Y. Sukjaya, Petunjuk Praktis untuk. Melaksanakan Evaluasi Pendidikan Matematika. Bandung: Wijayakusumah 157, 1990.

[11] G. Polya, How To Solve It. USA: Princeton University Press, 1973.

[12] I. Husna, “Jurusan Pendidikan Matematika Fakultas Keguruan dan Ilmu Pendidikan,” p. 17, 2017. 
Numerical: Jurnal Matematika dan Pendidikan Matematika, Vol. 2 No. 2 Desember 2018, 153-166

Ni Komang Vonie Dwianjani, I Made Candiasa, Sariyasa

[Halaman ini sengaja dikosongkan] 